\title{
Immigrant Teachers in Australia
}

\author{
Jock Collins \\ University of Technology, Sydney \\ Carol Reid \\ University of Western Sydney
}

\begin{abstract}
One of the features of contemporary society is the increasing global mobility of professionals. Australia is a major immigration nation with an increasing emphasis on selecting skilled and professional applicants. While have been an important component of skilled and professional immigration into Australia over past decades immigrant teachers, there is no comprehensive contemporary national study of the experiences of immigrant teachers in Australia. This article aims to fill this gap. It draws on quantitative and qualitative research with immigrant teachers in NSW, SA and WA to provide insights into the contemporary immigration experience of immigrant teachers. The article explores a number of stages in the immigrant teacher experience: their decision to move to Australia; their experience with Australian Education Departments in getting qualifications recognised their experiences as teachers in the classroom and in their lives in their new Australian community.
\end{abstract}

\section{Introduction}

One of the features of contemporary global society is the increasing brain circulation of professionals (Castles and Miller 2009; Goldin et al. 2011). While the education industry is a key site of the demand for contemporary global professional migration, little attention has been given to the global circulation of education professionals, including teachers and university lecturers. The labour shortage of educational and other professionals in western nations is partly due to demographic (supply) factors and partly due to the strong growth of the services sector in countries like Australia.

In 2003 the Organisation for Economic Co-operation and Development (OECD) reported that western nations like Australia face a serious shortage of experienced teachers within the next few years, with teacher shortages most likely in male-dominated secondary specialisations such as physics, chemistry, mathematics and technology studies, and languages other than English (OECD 2003). Two years later, the OECD recommended that OECD countries could learn from each other through "sharing innovative and successful [teaching] initiatives, and to identify policy options for attracting, developing and retaining effective [immigrant] teachers” (OECD 2005). 
As a consequence of global movements of teachers the Australian teaching workforce is being transformed by transnational flows of bilingual and multilingual teachers, itself an expression of, and response to, the complex phenomena named globalisation. Yet little is known about teachers from overseas in Australia. Who are they? Why do they come? What is their experience in Australian schools and with Australian Education Departments? Are their overseas teaching qualifications, skills and global experience valued in Australian schools? How do their students and their parents respond to their accents and cultural difference? What is their experience of life in Australian cities and regional and rural towns? Will they stay or will they go? Will they recommend to their international teacher friends to come to Australia and to teach in Australian schools? These questions are critical to an understanding of the contemporary Australian immigration experience in general, and to Australia's educational future in particular. This article draws on recent fieldwork with immigrant teachers in NSW, Western Australian and South Australia to begin to answer these questions.

The structure of the article is as follows. Section 2 provides some background on the history of immigrant teachers in Australia and a profile of immigrant teachers in Australia today. Section 3 presents and analysis of quantitative and qualitative primary data generated from fieldwork with immigrant teachers in schools in NSW, SA and WA conducted in 2008-9. It looks at their immigration experience and their experiences teaching and living in Australia. Section 4 draws together the major findings of this research into immigrant teachers in Australia.

\section{Immigrant teachers in Australia: background}

There is a long history of immigration to Australia in the past six-decades. Australia is an immigration nation where immigrants comprise a greater proportion of the population than most other western nations, with 26.5\% of the Australian population born overseas in 2009 (OECD 2011: 261). Australian immigration intakes reached record levels in recent years, with skilled permanent and temporary immigrants the largest component (Markus et al. 2009; Collins 2008). Over past decades, immigrant teachers have been an important component of skilled and professional immigration into, and emigration out of Australia. Australian trained teachers are sought after by other countries as part of the ‘brain circulation’ of education professionals (Robertson, 2007). 
Australia has a long history of teacher immigration. At various times in the past 6 decades up to 20 per cent of the Australian teaching force have been overseas trained (Inglis \& Philips 1995, p. 95). Up to the mid-1970s most teachers were directly recruited from the UK and Ireland, and this was later extended to the United States and Canada. More recently Australia's immigrant teachers also come from non-English-speaking countries in Asia and Africa, reflecting the changing patterns of Australian immigration following the end to the White Australia Policy in the early 1970s (Collins 2012). Australia has an experience of welcoming new immigrant teachers and farewelling Australian teachers who seek a temporary or permanent experience as part of the Australian Diaspora living in other countries. These two flows of teachers in and out of Australia have tended to balance out. According to Birrell et al. (Birrell, Dobson, Rapson, \& Smith 2001 cited in Fullilove \& Flutter 2004) Australia had a net gain of 1\% in relation to immigrant school teachers in the period 1996-2001.

With baby-boomer teachers now retiring, the future supply of Australian teachers is an issue confronting the public and private Australian education planners. In 2005 the Australian Education Union (AEU) suggested that since average age of the teachers across the nation was 49, Australian governments needed to implement specific policies to entice wellqualified professionals into their schools in a context of high attrition rates of teachers during the first five years of their career, the aging population of the teaching profession and increased teacher-stress (Australian Education Union, 2005). The Australian Education Union warned that with the average teacher retirement age being at 58 years, a very large proportion of current teachers in Australia would retire in the next ten years (AEU, 2005), given rise to warnings about impending teacher shortage which could amount to a crisis (Peeler \& Jane 2005). These concerns of teacher shortage in Australia were also voiced by the Ramsey Review (2000, p. 46) and a Department of Education, Science and Training report (DEST 2003, p. 74) on Australia's future. These reports emphasised the need to attract, prepare and retain quality teachers - including immigrant teachers - and also argued that teachers ought to reflect Australia's ethnic and cultural diversity. There is also evidence of an increase in the emigration of Australian professionals as part of the Australian Diaspora of 1 million (Hugo et al 2003; Hugo 2006) with other countries such as the UK seeking to recruit Australian teachers. For example, in the period July 2001-July 2005 Australia lost 5,819 trained teachers to the United Kingdom alone (Miller, Ochs, \& Mulvaney 2008). This loss of 
Australian-trained teachers to other countries adds to demographic factors to create gaps in the teaching labour market.

One solution is to train more teachers in Australia. Another is to lure Australian teachers back from other countries while a third solution is to attract and retain immigrant teachers to Australian classrooms. Similar issues confront countries such as Canada, the United Kingdom, and South Africa. In 2004 all countries in the Commonwealth agreed to the Commonwealth Teacher Recruitment Protocol (Commonwealth Teacher Recruitment Protocol, 2004) in attempt to address critical problems faced by national education systems and individuals alike. In other words, there is increasing global competition for teachers. An important part of a successful Australian recruitment and retention strategy of immigrant teachers is solid evidence-based research on the experiences of immigrant teachers in Australian schools.

While there has been some research on immigrant teachers in Australian schools (Bella, 1999; Han, 2004; Kamler, Reid, \& Santoro, 1999; Reid, 2005; Santoro, 1997, 1999; Kirchenheim \& Richardson, 2000 ), most of this is now dated and narrow in focus. The Australian College of Educators (2001) carried out a national survey that provided a tantalizing glimpse into the diversity of the teaching force but there are a number of factors related to the diversity and movement of teachers we still do not understand (A.C.E 2001). Some work has also been done on the specific contexts of individual states including WA (Dunworth 1997; Jones \& Soyza 2006) and Queensland (Bella 1999; Oliver 1998). Despite the increasing importance of understanding and responding to the global movement of teachers in Australia, there is no comprehensive contemporary national study of the experiences of immigrant teachers in Australia. This article aims to fill this gap.

This issue of cultural difference is central to Australian classrooms because of the cosmopolitan character of the Australian population, a consequence of Australia's large and diverse immigration program. As a consequence, the Australian primary and secondary school population is also very diverse in terms of ethnic, linguistic, religious and cultural background. In NSW, for example, $27.6 \%$ of secondary and $27.9 \%$ of primary enrolments in 2007 were from a LOTE (language other than English) background (NSW DET, 2008: 23) with Arabic, Chinese (Cantonese and Mandarin), Croatian, Dutch, Farsi, Fijian, French, 
German and Greek the top ten LOTE backgrounds of school students in NSW schools (NSW DET, 2008: 24).

According to 2006 national census data, as Table 1 shows, there are approximately 438,060 teachers in Australia. 74,620 of these, or 16.95\% of all teachers in Australia, were born overseas, that is, first generation immigrants. Compared to the proportion of the Australian population who were foreign-born at the time of the Census (24\%) immigrants are underrepresented in the Australian teaching sector.

Table 1 Birthplace of Australian Teachers

\begin{tabular}{|c|c|c|}
\hline Birthplace of Teacher & No. & $\%$ \\
\hline Australia & 356120 & 81.29 \\
\hline Overseas & 74260 & 16.95 \\
\hline Not Stated & 7680 & 1.73 \\
\hline Total & 438060 & 100 \\
\hline
\end{tabular}

Australia's immigrant teachers are drawn from countries around the globe. As Figure 1 shows, the majority of teachers - like the majority of all immigrants - were born in the UK and English speaking countries. Many immigrant teachers in Australia also come from New Zealand, South Africa, India, the USA, and Germany. Other immigrant teachers in Australia come from Europe, the Middle East, Asia, and South America, so that cultural, linguistic and religious diversity characterises the population of immigrant teachers in Australia.

Birthplace of immigrants is often a very crude measure of the cultural diversity of Australian society. For example, many ethnic Chinese immigrants are born in China, India, Fiji, Malaysia or the UK. As a consequence data on the ancestry of immigrants can assist in getting a more accurate picture of ethnic diversity of immigrants in Australia. Figure 2 presents ancestry data of teachers in Australia. By far the most common ancestry of teachers other than Australian is English, followed by other UK countries. However the very long 'tail' to this graph indicates the ethnic background of the Australian teaching profession is very diverse with those of European ancestries German, Italian, Dutch and Greek the largest cohorts of non-British ancestries. These are the second generation whose parents arrived in Australia in the 1950s and 1960s to work as labourers or shop-keepers but gave their Australian-born children an education to open the doors to professional employment. Chinese 
and Indian ancestries are the next largest group of teachers with 'minority' ancestries. These immigrants arrived in the past two or three decades and their numbers can be expected to increase significantly in coming decades as Asian countries often fill 8 out of the 'top ten countries of immigrant arrivals today.

Figure 1 Top 20 countries of birth for teachers born overseas

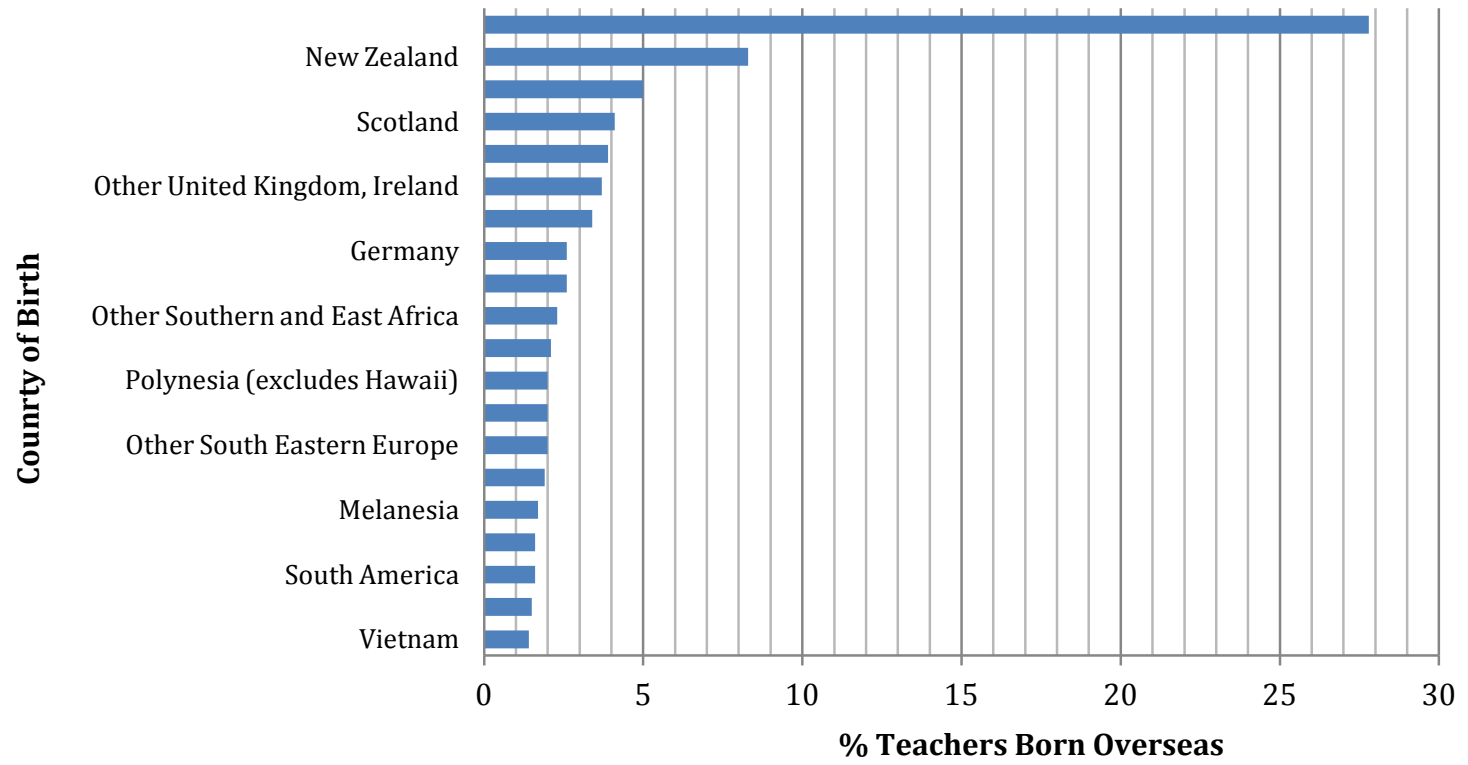

Source: compiled from 2006 national Australian census

Figure 2 Non-Australian ancestry of teachers in Australia

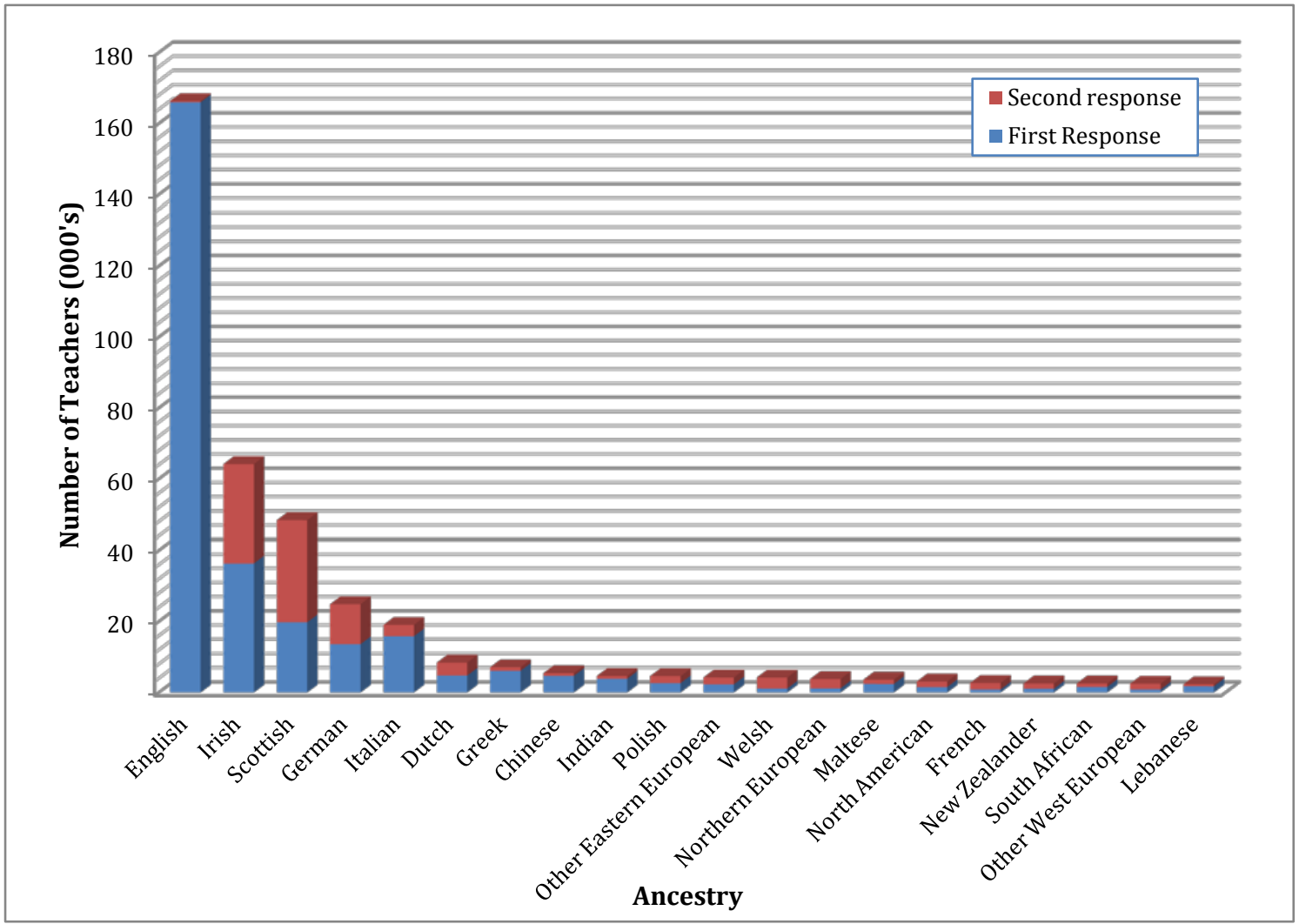

Source: compiled from 2006 national Australian census 


\section{A survey of immigrant teachers in Australia}

In this section we report the results of fieldwork conducted with immigrant teachers from three states. The fieldwork consisted of surveys of 269 immigrant teachers - NSW (197), SA (27) and WA (48) - conducted in 2008- $9^{1}$, focus groups of immigrant teachers and key stakeholder interviews conducted in each state. Teaching is a profession where the majority are women. Similarly our survey of immigrant teachers was predominantly (72.5\%) female. The immigrant teacher informants reflected the diversity of the Australian immigrant intake (Collins 2011). We first outline the characteristics of the immigrant teachers surveyed. We then explore their immigration experience, including the reasons why they wanted to come to Australia and their teaching experiences in Australia.

As Figure 3 shows, most of the immigrant teachers surveyed came from the UK (36\%), Asian countries (16\%), South Africa (13\%), New Zealand (9\%), and the USA and Canada (9\%). Others came from Africa with smaller numbers from European countries, Oceania, Latin America and the Middle-East.

Figure 3 Regions of birth of immigrant teachers in Australia (\%)

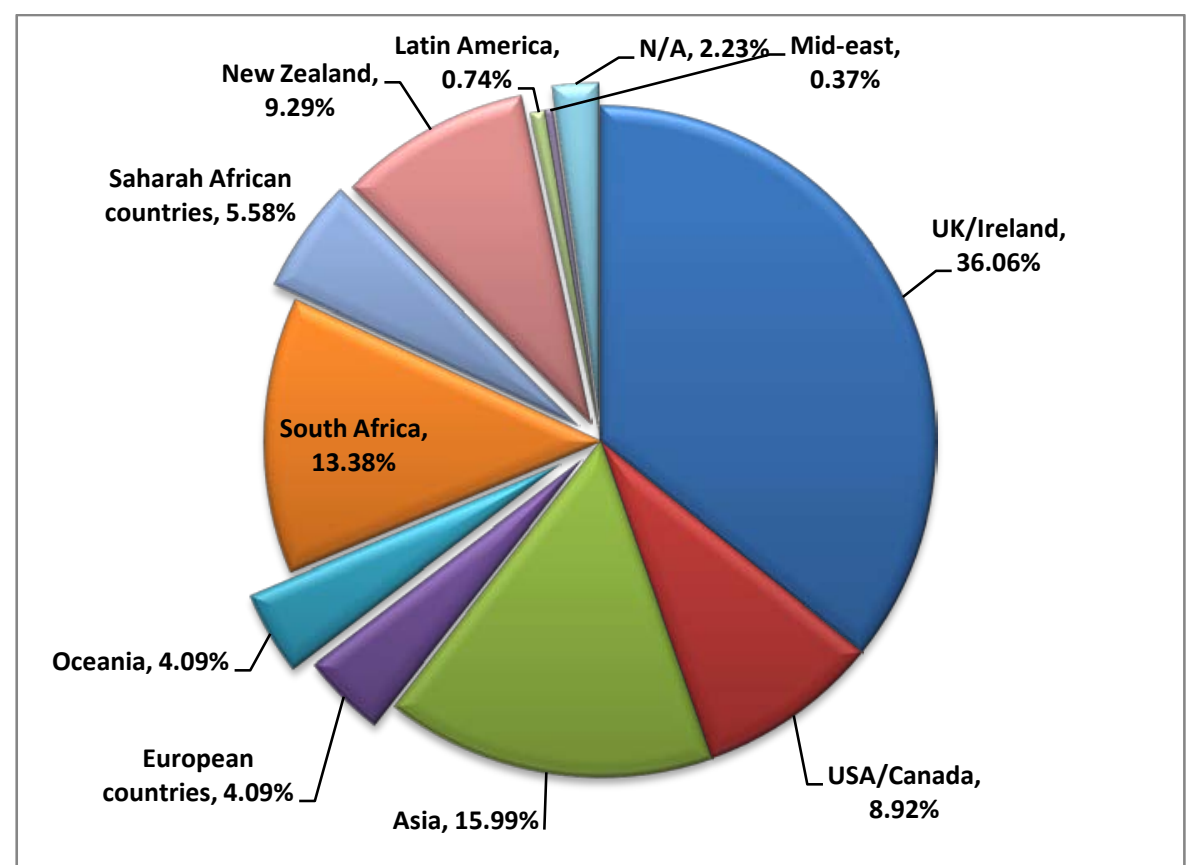

\footnotetext{
${ }^{1}$ The research was funded by an ARC Linkage Grant No. LP0668926: Globalisation and Teacher Movements into and out of multicultural Australia.
} 
One of the key economic benefits of immigration is that Australia gets professionally trained and experienced people whose education has been paid for by other coutnries taxpayers . These immigrants arrive not only with educational qualifications - human capital, in the language of economics - but also with experience working as education professionals. They fill gaps in the Australian teacher labour market. While they may be seen as a 'brain drain'from the point of view of the sending country, they are clearly a 'brain gain' for Australia.

These teaching professionals had accumulated substantial amounts of human capital in the form of teaching qualifications, with a number of teachers holding more than one teaching qualification. 198 immigrant teachers had a bachelors teaching degree, 65 had a masters degree and 10 held a doctorate. In addition, 78 immigrant teachers had a teaching diploma and 75 immigrant teachers had a teaching certificate (See Figure 4).

Figure 4 Immigrant teachers by teaching qualification by gender

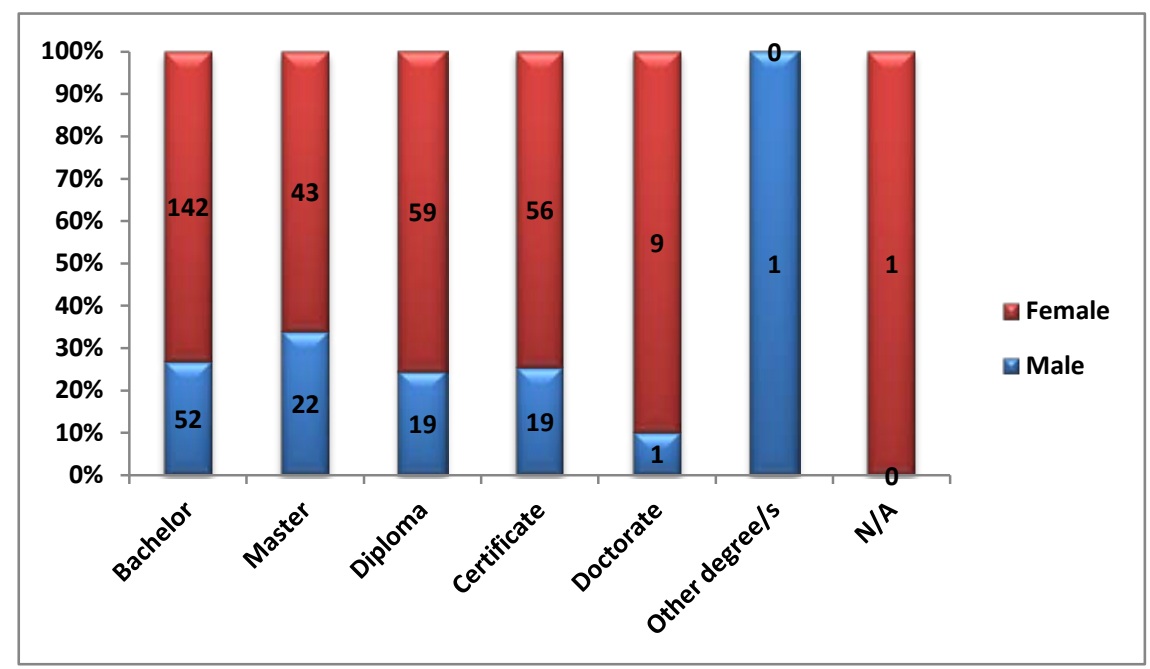

Teaching shortages in Australia are often specific to curriculum areas, to secondary, primary or early childhood education, to public or private sector schools or to specific geographical regions in metropolitan or regional and rural areas. Most of the immigrant teachers surveyed had qualifications to teach in secondary (155 immigrant teachers) or primary education (147 immigrant teachers), while another 44 had teaching qualifications in early childhood education. A number (31) also had qualifications to teach in tertiary education institutions. Women teachers surveyed were more concentrated in early childhood and primary education with the male teachers more likely to be teaching in secondary schools. 
One of the problems in the labour market for school teachers in Australian states is that a teacher shortage in one area of the curriculum (often mathematics and physical sciences) can co-exist with an over-supply of teachers in other areas, such as social sciences. As Figure 5 shows, the immigrant teachers who participated in the Australian survey had expertise and experience across all areas of the teaching curriculum. Immigrant teachers with expertise in English (with 48 immigrant teachers), Life Sciences (with 48 immigrant teachers), social science (with 48 immigrant teachers), and mathematics (with 25 immigrant teachers) were most numerous in the survey.

Figure 5 Areas of the curriculum in which immigrant teachers are trained

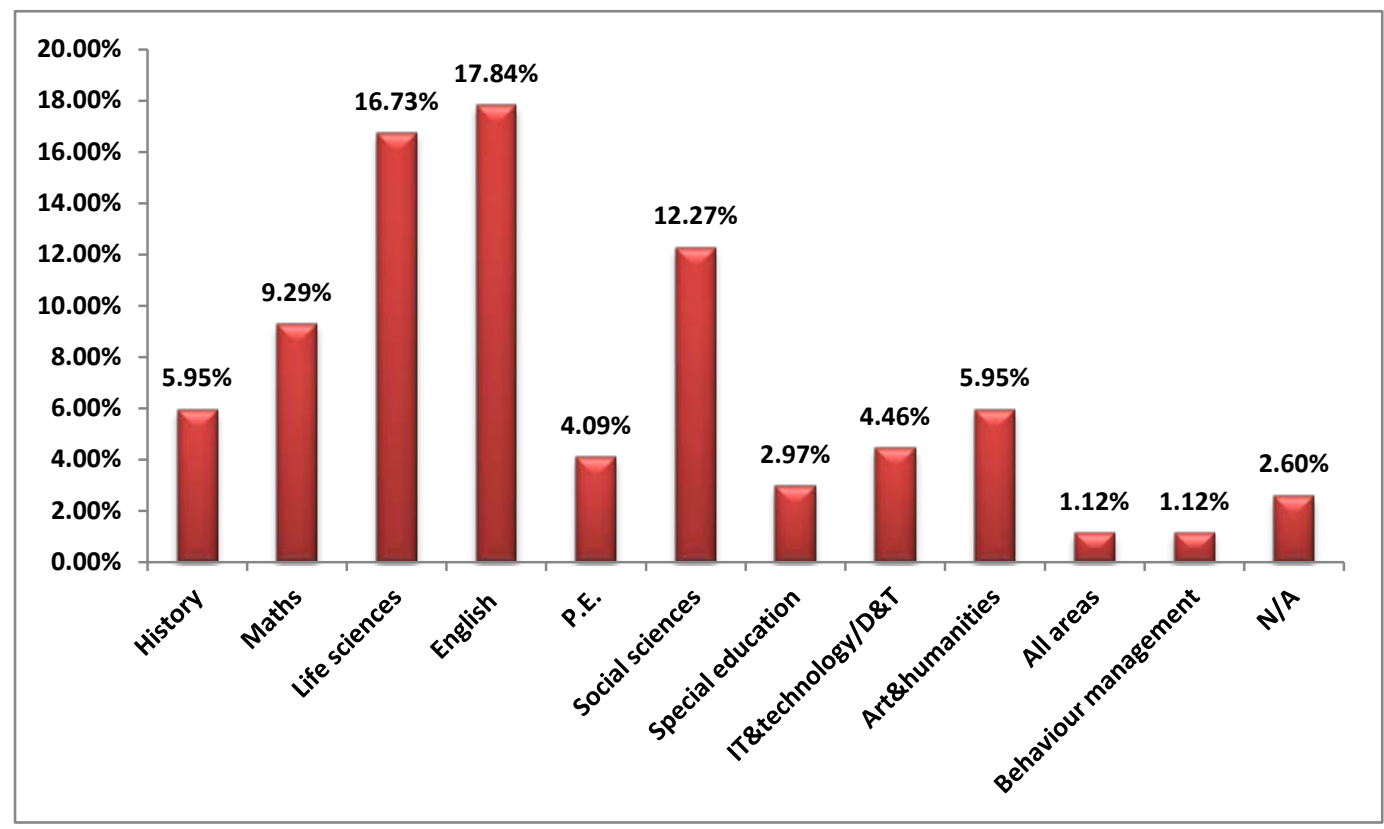

These immigrant teachers bring with them significant global teaching experience. As Figure 6 shows 120 immigrant teachers, or $45 \%$ of those surveyed, had taught in the UK or Ireland before coming to Australia to teach. Another 39 teachers (15\%) have taught in New Zealand schools, 38 (14\%) in South Africa, 36 (13\%) in schools in south-east Asian countries and 27 (10\%) in North America. Other teachers had teaching experience in European Union countries other than the UK, 18 in African countries other than South Africa and 14 teachers had experience in schools in the Oceania region other than NZ. The survey also included 9 informants with teaching experience in North East Asian schools, 2 in Arabic countries and 2 in schools in Latin America. 
Figure 6 The countries where Australia's immigrant teachers have previously taught (\%)

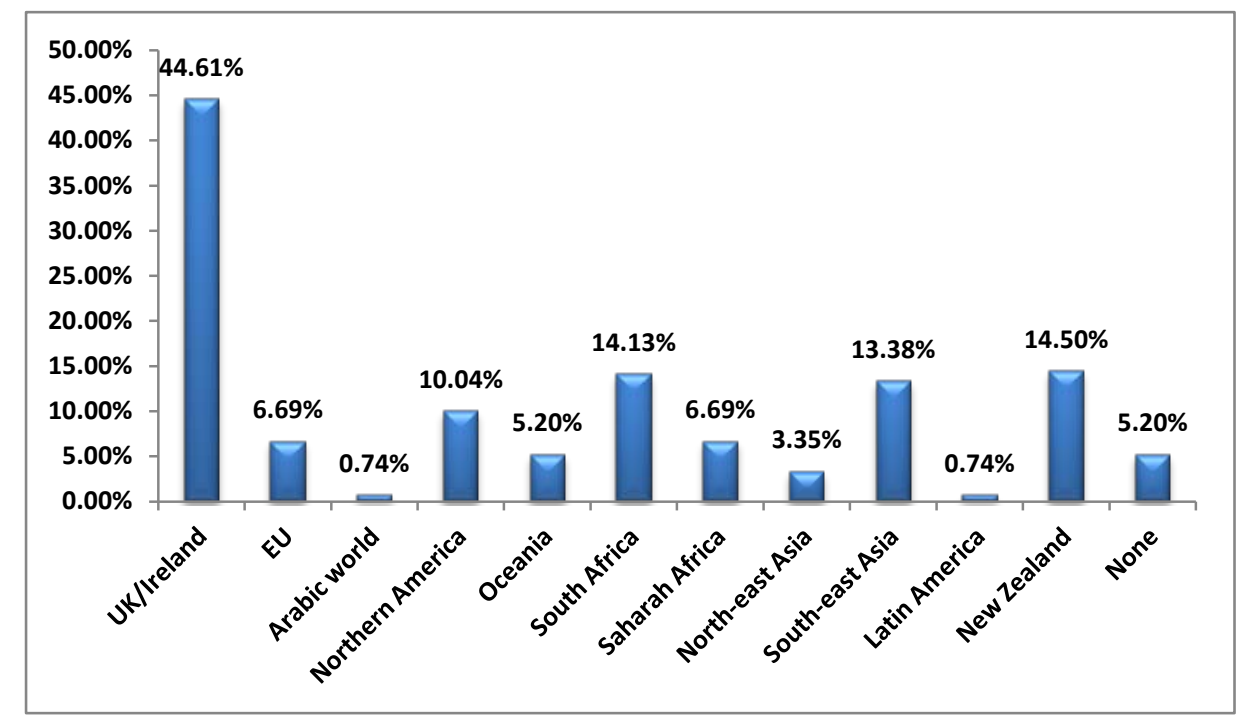

Note: 'none' means they only have taught in Australia as a foreign country. The majority who are in the category of 'UK/Ireland' are from the UK.

\section{Immigration Experience}

Immigrant teachers, like other professional immigrants, thus face considerable difficulties before they even get to work in Australia in their professional area, in their case before they get to teach in an Australian classroom. Deciding to leave their country, their family, friends, jobs and their familiarity to uproot themselves (and, where relevant, partner/spouse and other family members) to take the risk of trying their luck in a new country. This is a process that some 200 million immigrants have taken to date; the exceptional people, as Goldin and his colleagues call them (Goldin et al 2011), who are willing to take a step into the unknown with the hope of improving their life and securing a better future.

Australia draws in immigrants on permanent resident visas or temporary entrant visas. Immigration intakes to Australia reached record post-war levels in 2008-9, with an unprecedented rise in the proportion of temporary immigrants (mainly skilled and professional) in the immigration intake (Collins 2011). The process of immigration is itself costly, time consuming and difficult. Immigrant teachers draw on their social networks in Australia and on their direct and indirect knowledge of life in Australia to select it over other possibilities, the USA or Canada perhaps, or European countries, as their country of settlement.

The majority of immigrant teachers surveyed (75\%) arrived on permanent resident visas. This indicates the important role that permanent residence in Australia has in attracting immigrant 
teachers to Australia. About one in five immigrant teachers surveyed are on temporary visas, with most on the 457 visa or the spouse visa, with a few on student or working holiday visas. The majority of those surveyed on temporary 457 visas came to Australia with the specific intention to teach, using their professional educational qualifications and teaching experience as a passport to get sufficient points to enter Australia under the points-test selection process. However, only one in three who came as part of the permanent immigration intake planned to teach in Australia at the time of immigration.

The survey explored the reasons why those who came to Australia with the specific intention to teach wanted to teach in Australia. As Figure 7 shows, the top reasons given are professional ['teaching is my occupation'/ 'enjoy teaching' (20\%), 'better resource/professional development' (17\%)] and lifestyle ['better lifestyle' (8\%) and 'to live life' (3\%)]. It is interesting that 'spouse' or 'family reunion/migration' is no longer a prominent reason for teaching in Australia although considerations about 'spouse' is a key factor impacting on the decision to migrate to Australia.

Figure 7 Why did you want to teach in Australia?

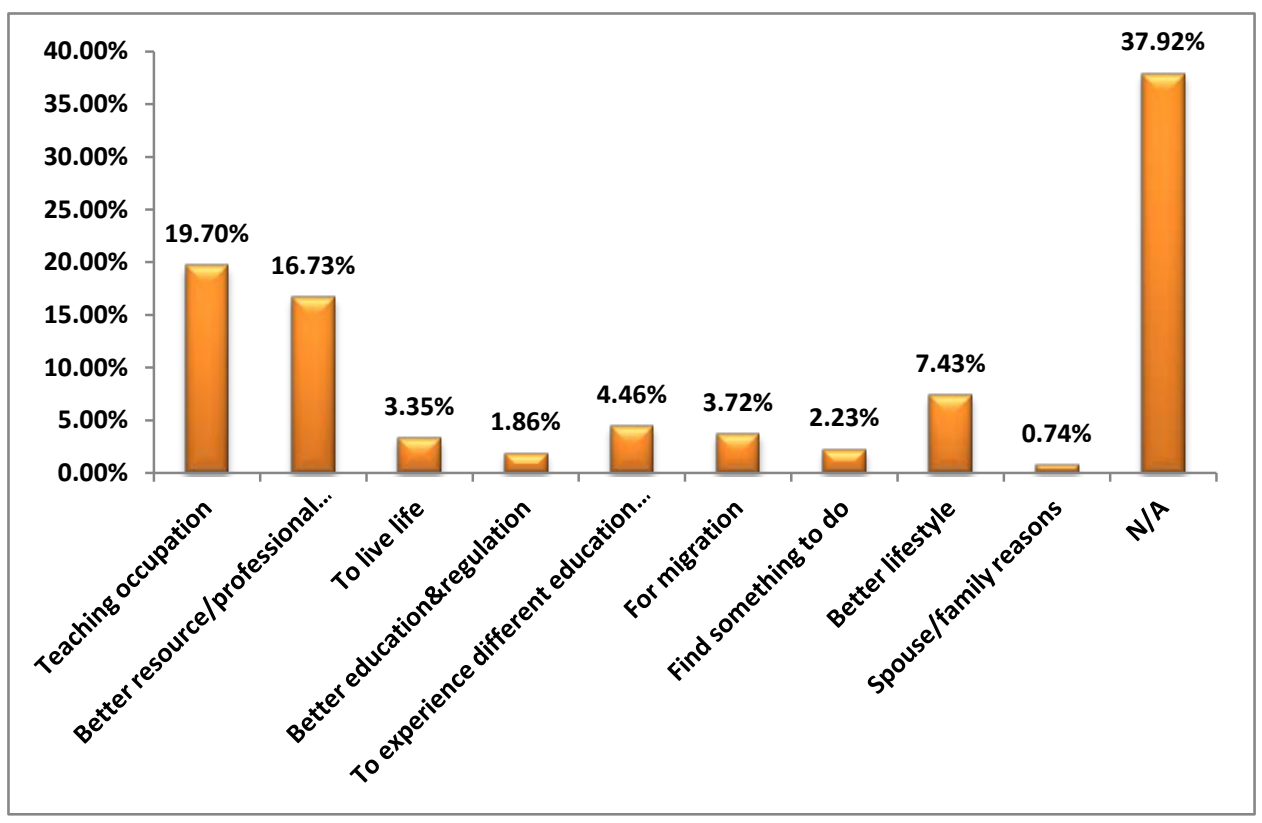

Some immigrant teachers came to Australia for better career opportunities. Here are two NSW immigrant teachers: “I came, I don’t know word of mouth or how, believing Australia was desperate for teachers”; “ I heard a lot about Australian schools and I heard that education was excellent here”. Others came for the future of their family: As three NSW 
immigrant teachers put it: We thought it would be better job opportunities for our children”; "Because of the racial discrimination, we were not quite settled but we moved on to greener pastures. A better life for yourself and the kids.”; “It’s peaceful here, and yes, that's the main thing, we want peace". Others came because of push factors: "We immigrated as a family I think because of the political turmoil in South Africa. (NSW). For others it was family connections: "My sister was here already so, too, family member.”; "I actually came with my husband who is a doctor at Griffith Base Hospital. - I met an Australian man and we decided that we would shift out to Australia”.

One of the realities for globally-mobile professionals the world over is the issue of qualification recognition and professional certification in the countries that they emigrate to. Often this process does not go smoothly enough for, or meet the expectations of, or promises made to, the immigrant professionals themselves. One of the strongest themes that emerged from our fieldwork is the dissatisfaction with the red tape that goes with the institutional requirements that immigrant teachers must meet in Australia before beginning employment in Australian schools. Different professions have different registration procedures and for immigrant teachers these registration procedures and requirements vary from state to state. For immigrant teachers, this means getting their teacher qualifications recognised in Australia, undertaking teacher induction programs to familiarise them with the Australian education system which varies from State to State. Half of the immigrant teacher informants - those from non-English-speaking countries - went through processes to assess their English Proficiency. Most of those surveyed complained about the time consuming and unnecessary paper work they confronted before being allowed to teach and reported that they had problems with the bureaucratic systems and processes that they encountered in Australia schools.

\section{Experience in Australian schools}

The final hurdle is to secure a teaching job in Australia. Once appointed to a school, Australia's immigrant teachers experience emotions of uncertainty mixed with the satisfaction of beginning the final leg of their global teacher journey. This can be a quite stressful, lonely and uncertain time for an immigrant teacher: The journey to an unfamiliar location; the need to find new accommodation; having to meet with the principal and fellow teachers for the first time; and, finally, standing in front of your new students in an Australian classroom. Now begins the experience of being an immigrant teacher in Australia. 
Most immigrant teachers surveyed found a teaching job in the public teaching sector, but the majority of these could only secure temporary or casual teaching positions. A permanent teaching position is difficult to achieve in Australia, particularly in the large cities such as Sydney, Adelaide and Perth. There are more openings for permanent teachers in nonmetropolitan schools, particularly in those schools located in rural and remote areas where the lifestyle is not as attractive to young Australian-trained teachers. More immigrant teachers surveyed were employed in rural and remote regions than in metropolitan schools.

What is it like to be an immigrant teacher in Australian schools? What barriers and difficulties do they do they face and how are these issues resolved? Are the global teaching experience and skills as immigrant teachers valued? What is the response to immigrant teachers and their cultural difference from other members of the teaching staff, from students and their parents? What opportunities do immigrant teachers get for professional development and promotion? Does the actual experience as a teacher in Australian schools match their dream and expectations? Will they stay or will they go? Will immigrant teachers recommend to their teacher friends back home or teaching in other countries to come to Australia to teach? All these questions are critical to the ability of Australia to compete successfully in the competition for global teachers, to attract and retain sufficient immigrant teachers in coming decades to fill shortages in the Australian teacher labour market. In this section we answer these questions.

We asked immigrant teachers: 'what difficulties, if any, have you faced as an immigrant teacher in Australia?' The most common answer (Figure 8) was that immigrant teachers had problems with the bureaucratic systems and processes that they encountered in Australia schools. The difficulties that ranked next in order of immigrant teacher responses were: discrimination/racism; employment difficulties; and lack of support. Other difficulties noted by immigrant teachers were qualifications NOT recognized/appreciated; student behaviour, issues related to curriculum, welfare issues and cultural gap/way of doing things.

Perceptions of discrimination and racism took a number of forms. One related to responses to the immigrant teachers' accent, especially in classroom settings. A number of immigrant teachers from Africa and India reported negative responses to their accent, as did teachers with American and Irish accents. Some commented that their accent had been mocked, or that 
other negative feedback had occurred as a result of it. One female from a school just north of Perth reported the following experience: "Yesterday, I got a new class, Yr9 students; it happened that the other teacher was doing something else so they asked me to go to that class, and I came to the class and they started laughing. And I said why are you laughing guys? And they said, oh, your accent is so funny. I said, oohh, and then you have to laugh so much. I wasn't (pauses - very upset)”.

Figure 8 The difficulties that immigrant teachers faced in Australian schools

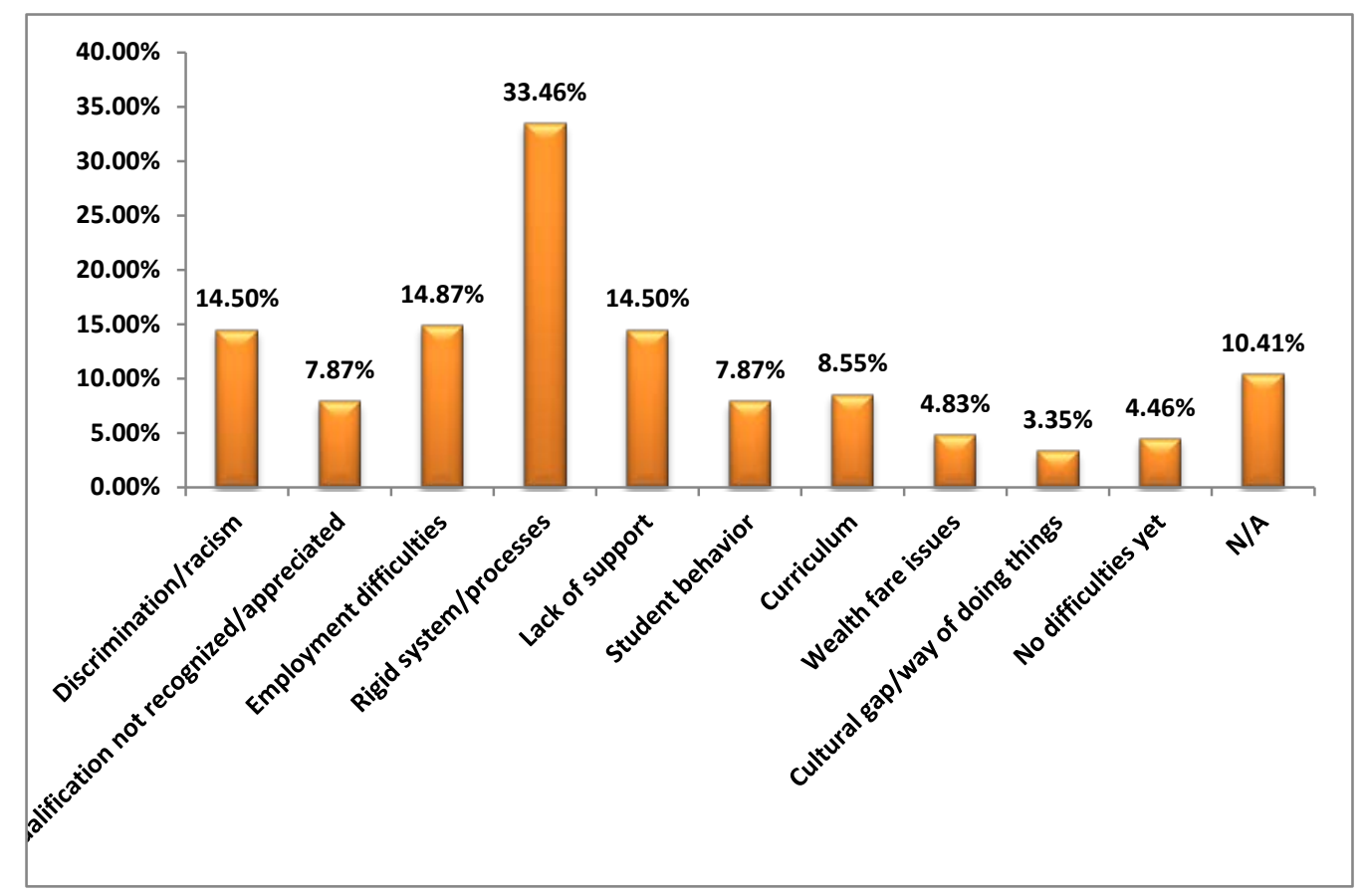

Another teacher in WA with an Irish accent reported one incident with students in the classroom: “you must find my accent, because you know being a bit Irish, you know, you must find my accent very strange here in Australia and they said 'no no, you just go wah, wah, wah"”. A female teacher in NSW said "I just felt, I always felt self conscious, I always felt that my accent all the way interfering with my knowledge so yeah, I wasn't comfortable”. Such racist responses to immigrant teachers by students hit immigrant teachers hard. As one female teacher in a regional school north of Perth put it, "it makes me feel devalued as a person because he's telling me a blatant lie, and I think just because I've got an accent doesn't make me stupid”.

Immigrant teachers often responded to instances of perceived racism from students. Here is an account of a male teacher in a NSW school: "Last year, somewhere in the end of the year, 
I have a reported 3 guys in $\operatorname{Yr} 11$ that I was ah, sort of provoked and discriminated because of my accent, they did that purposely when I was telling them you should go somewhere from here or move or you out of bounds, they said what, I don't understand you and such things, so I reported this as sort of a provocation and discrimination to the Deputy Principal”. Similarly, another NSW male teacher from India recounts the following experience of racism: "There is racism, and especially from the students here they will laugh at you... the curry munchers, they'll talk about you like that and the words sound differently from them, I heard at the beginning, I used to tell my head teacher, some Yr7, Yr8 when I had them for the first time, they'll try to use the word curry muncher in front of me for me to hear, so I'll turn around and give them a smile and say oh, I love my curry”.

Racial discrimination in the workplace either stands as a barrier to employment in the first instance or a constraint on their working lives once in a job. One concern of immigrant teachers in Australia is where they stand in relation to promotion. We sought responses to the question: 'Immigrant teachers in Australia are as likely to be promoted as non-immigrant teachers to jobs for which they are qualified and eligible.' About the same proportion of the immigrant teachers surveyed agreed (8\%) to or strongly agreed (25\%) to the proportion as those who 'disagreed' (19\%) or 'strongly disagreed' (12\%). The remaining 36\% were either neutral (30\%) or did not answer (6\%). The suggestion here is of a substantial number of immigrant teachers' perceptions of discrimination against immigrant teachers in the processes and procedures (formal and informal) related to promotion.

In relation to the concern about fairness in employment and promotion, it is interesting to note that only one teacher interviewed reported promotion within an appropriate timeframe (2 years) of beginning teaching in Australia. She had taught for 16 years in a number of countries but the recognition was purely based on her teaching in Australia. A young Chinese background immigrant teacher felt that being an ethnic minority would make it harder to gain promotion. "Yeah, and, sometimes it's a bit hard for ethnic Australians to get into the top positions. This is true in the profession, for local teachers, and sometimes this is hard, so what I'm looking at is just do my job well and make a difference in my expertise, that's it, yea". A young woman of American background commented: "I have also experienced a lot of professional prejudice, because I never understood the tall poppy syndrome, but I understand it now”. 
In focus groups with immigrant teachers, concerns with racism emerged at a number of levels. From the metropolitan area, a young female teacher said: "Other teachers, my line manager, it's seen as a threat if you try to improve anything, and I can't tell you the amount of time I've been told 'stop it you American'”. As one NSW teacher put it, "Yeah, so, in terms of promotion, I feel very much as though there are 5 teachers who have been there very much longer than I have, they're Australians, they are going to climb the ladder much faster than our kind".

So overall how did immigrant teachers rate their experiences of uprooting themselves and families, taking the long journey to Australia, going through bureaucratic red tape and, finally, teaching in Australian schools, Was it all worth it? The research suggests the answer is mixed, with roughly equal numbers satisfied and dissatisfied with their experience as a global teacher in Australia. Figure 9 shows that those who responded that their expectations of being a teacher in Australia been met (80 or 30\%) only slightly outnumbered those who reported that their expectations of being a teacher in Australia had not been met (67 or 25\%). Another three in ten respondents had their expectations only partly met. If the key issue is the attraction and retention of immigrant teachers to Australia, this finding is of some concern. The informal feedback that the unsatisfied teachers give to their peers considering a similar move to migrate to Australia as a teacher would not be positive. Moreover, it is likely that dissatisfied immigrant teachers in Australia might think of returning home, moving to another Australian state to teach or going to yet another country as an immigrant teacher.

Figure 9 Have your expectations of being a teacher in Australia been met?

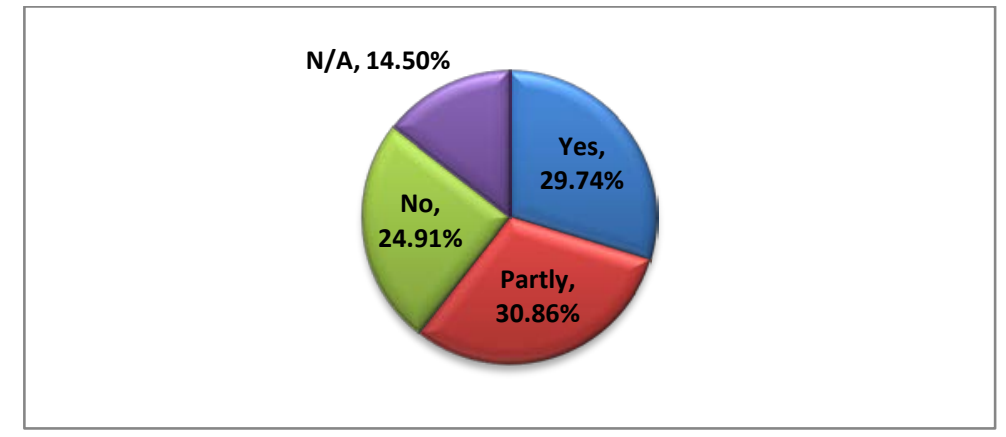

One immigrant teacher from WA reflected on those teachers who are dissatisfied: "I know that teachers from overseas who arrive now seem to be discontented that the reality of teaching here does not meet their expectations. They feel that they are promised better wages and conditions than they actually receive." 
We also inquired about the extent to which the immigrant teachers in NSW, SA and WA were satisfied with their immigration to Australia from a personal, rather than teaching professional, perspective. Once again, only a slight majority reported that they were satisfied (105 or 39\%) rather than unsatisfied (80 or 30\%) from this point of view (Figure 10).

Figure 10 Satisfaction as a teacher in Australia from a personal perspective

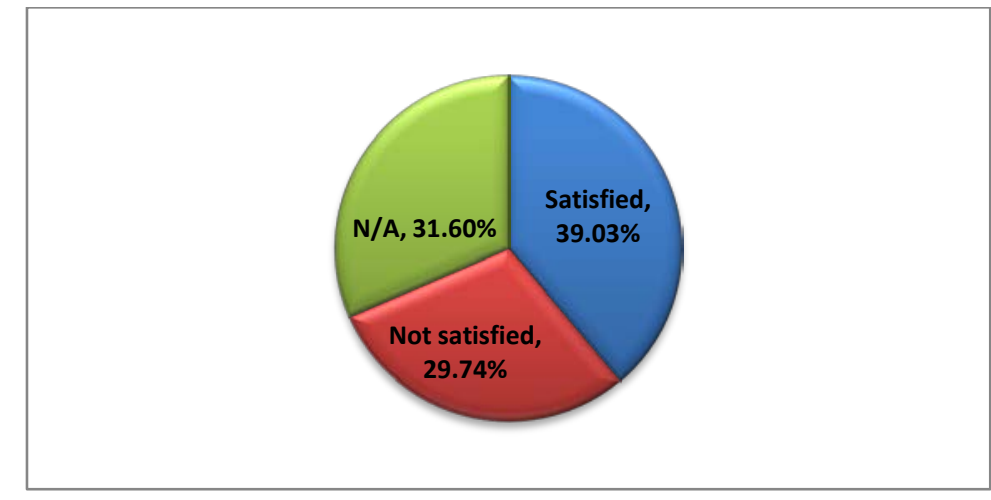

Teacher labour shortages are strongest in regional and rural communities. Working in regional communities brings new experiences for immigrant teachers. A focus group participant in a WA regional mining centre summed up his experience: “But dealing with people and trying to get to know people, cause I think people in a town like this are a little bit wary of getting involved with you because it is such a transient town as well, and you know, so it's a bit of a tricky one to get to grips with, especially if you are coming from a very highly populated area to where everybody is kind of in your face and you know, it can get a bit lonely at times and that sort of thing”. Other immigrant teachers find themselves isolated for reasons of cultural difference in communities as a metropolitan teacher explained after finishing a period of time in regional area: “They were, I mean obviously I got flak, cause I was you know, a Pom, and I that's great I mean that didn't bother me at all, it doesn't bother me now and that was the way it was out there, that was the community and yeah, and they were just lovely people, very friendly”. A teacher from Kenya who was teaching in a wellresourced mining town commented that he had plenty to do through organised sport: “...but the culture and the society that can be really difficult and I think that's what really frustrates most new teachers".

A young Irish woman in a focus group in a regional coastal town recounted her story of her difficulty in settling in as an immigrant teacher: "Lots of tears were shed in the first 6 months 
because I had no support, I couldn’t go see a doctor, I had to go home, I still haven’t been able to see a dentist I think I'll have to go home for that too".

Some immigrant teachers, particularly those places in remote regional and rural schools, reported difficulty in dealing with Indigenous students. One immigrant teacher placed in remote WA schools commented: "And then if you do 2 years there then you can get permanent residency. But if you're coming from inner London, and end up going to Fitzroy Crossing or way up in one of the really remote areas in the Kimberley, total culture shock, you've got the weather, you've got the Aboriginal culture, which is totally beyond anything that anybody would've experienced”. Another immigrant teacher in a regional WA school had this story to tell: "It goes very quick, when I first came with my family I said what the hell am I doing here and it was a huge culture shock coming to this school because in Perth we used to see indigenous people, they weren't in your face, I didn't really have to talk to them, not that I didn't want to but I didn't have anything to do with them, and then you go into a classroom where you have 50-60\% indigenous kids and it's like ' $\mathrm{f}$ ' you miss and you bitch and I used to go home crying...I am really tired; these kids are giving me a hard time...That is a big issue here I find that I did not find in Perth. I taught there as well but when I came here I found there was a big gap between the two groups and last month there was actually some kind of communal fight which I had to sort out in my own way because we are expected to do things for Aboriginal kids which we are not expected to do for the white kids. Now that I find is something that can be put in as discriminatory”.

It is interesting to note that most of the immigrant teachers surveyed in NSW, SA and WA rated their work 'very favourably' (14\%) or 'favourably' (45\%) compared to their experience working as a teacher in another country. Only 40, or about $15 \%$ of the immigrant teachers surveyed, rated Australian teaching as 'not very favourably' or 'very unfavourably' compared to their experience working as a teacher in another country. (27\% did not answer the question.)

The immigrant teachers in Australia were asked to reflect on their experiences to date and were asked: 'If you were able to make one major change to education policies or procedures, what would that change be?' Figure 11 shows the responses to this question. There were a very broad range of responses, with the most common suggestion (about one in five responses) relating to making it easier to navigate the administrative and institutional 
pathways that new immigrant teachers must travel to be permitted to front a classroom in an Australian school. One in four wanted policies related to immigrant teachers changed, while another one in ten complained directly about the application process in Australia. The two other most common responses related to suggestions about school processes and procedures: student related issues and the need for increased support. Work and employment conditions were of concern to 33 immigrant teachers. A few respondents raised suggestions about curriculum issues.

Figure 11 If you were able to make one major change to education policies or procedures, what would that change be?

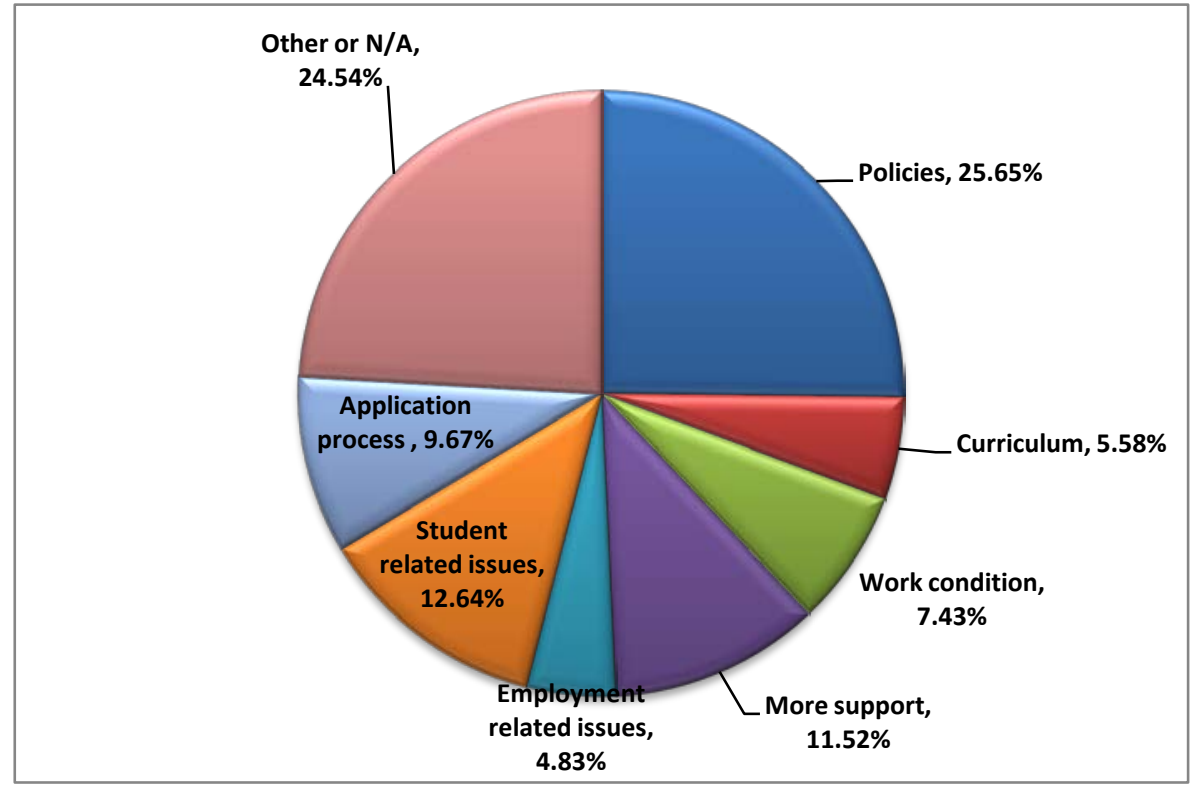

\section{Experience Living in Australia}

An immigrant, permanent or temporary, comes to Australia not only to work but also to live. They become workmates in schools and neighbours in the suburbs, cities or towns where they settle. The immigrant experience is at once professional and social. As Figure 12 shows, most of the immigrant teachers in NSW, SA and WA did get involved with their new local community: Three in four (72\%) were regularly engaged in activities involving sports or hobbies while a slight majority regularly attended activities arranged by the local school or by the local community. One in three immigrant teachers regularly attended activities arranged by people from their home country. This evidence suggests that many immigrant teachers are embraced by their 'host' neighbourhood and school community forming social networks that assist decisions to stay rather than to go. 
Figure 12 Since coming to Australia have you regularly attended any of the following activities?

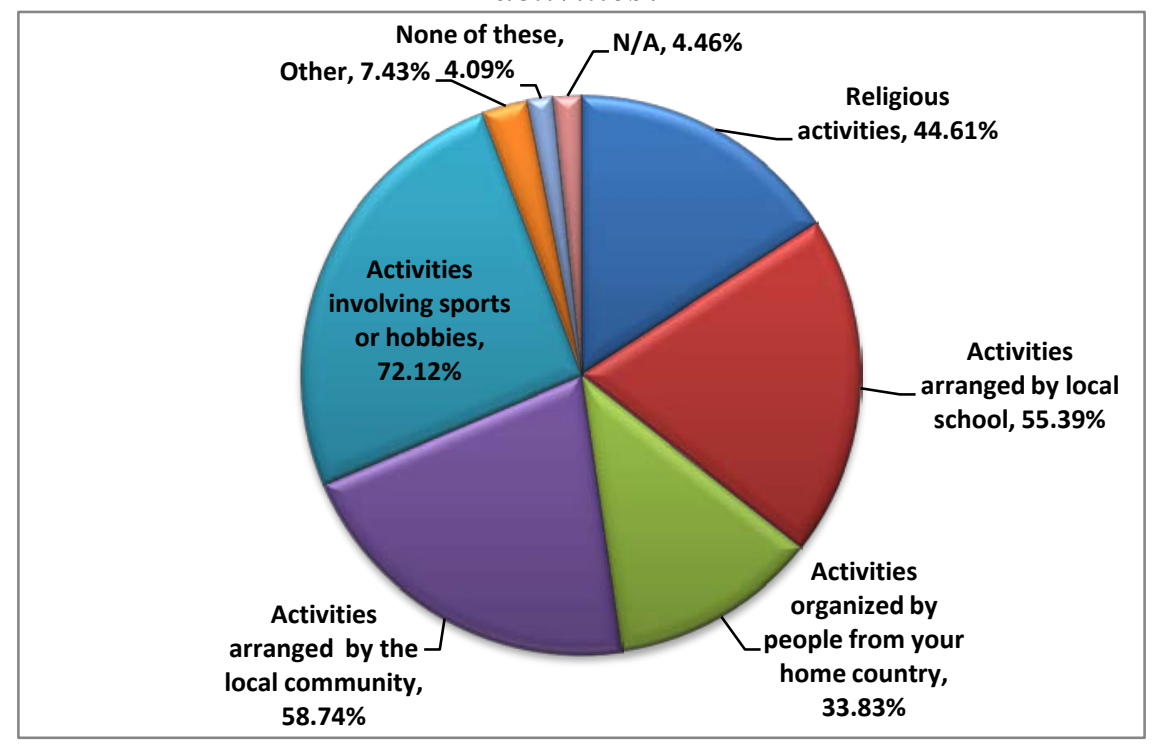

A critical question to evaluate an immigrant experience in a country like Australia is: 'have you or would you recommend to other immigrant teachers that they teach in Australia?' 60\% of all respondents said that they have or would recommend to other immigrant teachers that they teach in Australia. This finding is very relevant to the issue of the attraction of new immigrant teachers to Australia. This is a very positive endorsement for the experience of immigrant teachers in NSW, SA and WA. Responses to this question are not sensitive to gender differences.

Another critical question, this one relevant to the issue of the retention of new immigrant teachers, to evaluate an immigrant experience in a country like Australia is: 'in five years time do you see yourself teaching in Australia?' Two in three (64\%) of all respondents, or $75 \%$ of those who provided an answer to this survey question, said that they do see themselves teaching in Australia in five years time. This is also a very positive endorsement for the experience of immigrant teachers in NSW, SA and WA. Responses to this question are not sensitive to gender differences.

\section{Immigrant Teachers in Australia: An overview}

In this article we have drawn on new quantitative and qualitative research to explore the experience of immigrant teachers in Australia. We now have a much better understanding of who these immigrant teachers are, where they came from, why and how they came to Australia. We also have important insights into their experiences on arriving in Australia of 
getting their teaching qualifications recognised, getting teacher registration in the States in which they settled and getting their first school appointment. We can also better understand the experiences of these immigrant teachers in their schools and the Australian communities into which they settle. And we know if they are likely to stay or to go.

While Australia has a long history of importing teachers from other countries, there are major differences evident in teacher immigration in the past few decades. First, whereas most immigrant teachers came from the UK in the first post-war decades, in recent decades more immigrant teachers have been coming to Australia from Asian and African countries, with India and South Africa in particular important source countries for today’s Australian immigrant teachers. Second, immigrant teachers today include temporary as well as permanent immigrants. One in four of the immigrant teachers we surveyed arrived on temporary 457 skilled-worker visas. They were mostly from Western Australia - the state that deliberately attended Australian Immigration Expos to directly recruit teachers.

Immigrant teachers are, of course, highly educated. Two in three have an undergraduate university degree while another one in five had a post-graduate university qualification. The contradiction is that most teachers surveyed reported that they had experienced problems with qualifications recognition and teacher registration - that is, problems with the red tape of the State Education Departments. Despite this, the majority were generally satisfied with their experience in Australian schools: three in four liked their job, despite bad experiences in the form of negative responses to their accents from students or barriers to their promotion within the school. Many teachers reported negative responses by students, other teachers and parents to their accents. Interestingly some teachers with Irish, American and South African accents, as well as those who came from India and Africa, perceived negative responses to their cultural difference. Most also appear to be generally satisfied with their experience as an Australian immigrant. They are connected to other people where they live, participating in sport and leisure activities, and attending local social activities that are religious, based in their schools or their local community while one in five have social networks with other immigants from their country. On the other hand, half of Australia’s immigrant teachers think that there is racial dicrimination in Australia, although only one in ten think that there is a lot of racism in Australian society. 
The conclusion then is that the immigrant teacher experience in Australia is a mixed bag from the point of view of professional teaching experience and as an immigrant living in Australia, though the majority judge that the benefits and positives outweigh the negatives. Overall, those who responded that their expectations of being a teacher in Australia been met (80 or $30 \%$ ) only slightly outnumbered those who reported that their expectations of being a teacher in Australia had not been met (67 or 25\%). Nevertheless most immigrant teachers rated their experience as a teacher in Australia favourably or more favourable when compared to their teaching experience back home. From a social point of view, most immigrant teachers had connected to their new communities and regularly attended sporting and social activities. This may explain why $60 \%$ of all respondents said that they have or would recommend to other immigrant teachers that they teach in Australia and why two in three immigrant teachers surveyed said that they expect to be still teaching in Australia in five years time.

\section{References}

Australian College of Educators 2001, Teachers in Australian Schools: A Report from the 1999 National Survey. Executive Summary. ACT: Department of Education, Training and Youth Affairs.

Australian Education Union 2005, A National Teacher Shortage: A Solution from the Australian Education Union Retrieved 2 September, 2005, from http://www.aeufederal.org.au

Bella, M. 1999, A New Beginning: Overseas Teachers and the Queensland Education Context. Queensland: Board of Teacher Registration and Multicultural Affairs Queensland.

Birrell, B., Dobson, I. R., Rapson, V., \& Smith, T. F. 2001, Skilled Labour Gains and Losses. Melbourne: Centre for Population and Urban Research, Monash University.

Castles, S., \& Miller, M. J. 2009, The Age of Migration: Population Movements in the Modern World (3rd ed.). Palgrave Macmillan, New York.

Collins, J. 2008, 'Globalisation, immigration and the second long post-war boom in Australia’, Journal of Australian Political Economy, no. 61 June 2008 pp. 244-266.

Collins, J. 2011, 'The governance of immigration in Australia' in Nicola Phillips (ed) Migration in the Global Political Economy, Volume 17, International Political Economy Yearbook Series, Lynne Reinner Publishers, Boulder, pp 231-255.

Collins, J. 2012, 'Integration and inclusion of immigrants in Australia', in James Frideres and John Biles (eds.) International Perspectives: Integration and Inclusion, McGillQueen's University Press, Montreal, pp. 17-37.

Department of Education, Science and Training, 2003, Australia's Teachers: Australia's Future - Advancing Innovation, Science, Technology and Mathematics. Committee 
for the Review of Teaching and Teacher Education, Commonwealth of Australia, Canberra.

Dunworth, K. 1997, An Investigation Into a Hidden Asset: a Study of Overseas Trained NESB Teachers in WA. Department of Training, Human Resources, Perth.

Fullilove, M., \& Flutter, C. 2004, Diaspora: the World Wide Web of Australian (Lowy Institute Paper 04). Lowy Institute for International Policy, Double Bay, NSW.

Goldin, I., Cameron, G. and Balarajan, M. 2011, Exceptional People: How Migration Shaped Our World and Will Define Our Future, Princeton University Press, Princeton.

Han, J. 2004, 'Teacher shortages, bilingual teachers and the mobility of trans-national knowledge workers', Melbourne Studies in Education, vol.45, no.2, pp. 99-114.

Hugo, G., 2006, ‘An Australian Diaspora?’, International Migration, vol.44, no. 3, pp.105132.

Hugo, G., Rudd, D., \& Harris, K. 2003, Australia's Diaspora: Its Size, Nature and Policy Implications: Committee on the Economic Development of Australia.

Inglis, C., \& Philips, R. 1995, Teachers in the Sun: the Impact of Immigrant Teachers on the Labour Force. Australian Government Publishing Service, Canberra.

Jones, M., \& Soyza, J. D. 2006, Good Practice Initiativs in the Recruitment and Placement of Overseas Trained Teachers. WADET, Perth.

Kamler, B., Reid, J., \& Santoro, N. 1999, 'Who's Asking the questions? Researching race, ethnicity and teachers', The Australian Educational Researcher, vol.26, no.1, pp. 5573.

Kirchenheim, C., \& Richardson, W. 2000, 'Teachers and their international location: the adjustment of self-efficacy and flexibility on Adjustment and Outcome Variables. International Education Journal, vol.6, no.3, pp. 407-416.

Markus, A., Jupp, J. \& McDonald P. 2009, Australia’s Immigration Revolution, Allen \& Unwin, Sydney.

Miller, P. W., Ochs, K., \& Mulvaney, G. 2008, 'International teacher migration and the Commonwealth teacher recruitment protocol: assessing its impact and the implementation process in the United Kingdom', European Education, vol.40, no.3, pp. 89-101.

NSW Department of Education and Training 2008, Schools and Students in New South Wales, 2007: Statistical Bulletin (www.det.nsw.edu.au/reports_stats/stats/ schools.htm)

OECD 2003, 13-14 November 2003, Public Management Committee, Country Fact Sheets. Paper presented at the 28th Session of the Public Management Committee, Chateau de la Muette, Paris.

OECD 2005, Teachers Matter: Attracting, Developing and Retaining Effective Teachers, Paris, OECD.

OECD. 2011, International Migration Outlook, SOPEMI 2011. OECD, Paris.

Oliver, K. 1998, Manging Diversity in Our Schools: Counting Our Target Groups and Making a Difference. Paper presented at the Australasian Association for Research in Education Annual Conference. from http://www.aare.edu.au/98pap/oli98322.htm

Peeler, E., \& Jane, B. 2005, 'Mentoring: immigrant teachers bridging professional practices', Teaching Education, vol.16, no.4, pp. 325-336. 
Ramsey, G. 2000, Report of the Review of Teacher Education. Sydney, Department of Education.

Reid, C. 2005, 'Global teachers with Globite cases’, Australia Journal of Education, vol.49, no.3.

Robertson, S. L. 2007, 'Brain drain, brain gain and brain circulation', Globalization, Societies and Education, vol.4, no.1, pp.1-5.

Santoro, N. 1997, 'The construction of student teacher identity: an analysis of school practicum discourse', Asia Pacific Journal of Teacher Education, vol.25, no.1, pp. 9199.

Santoro, N. 1999, 'Relationships of power: an analysis of school practicum discourse', Journal of Intercultural Studies, vol.20, no.1, pp. 31-42. 